\title{
Læring, kommunikation og samarbejde i virtuelle rum
}

\author{
Marianne Georgsen \\ Institut for Kommunikation \\ Aalborg Universitet \\ marianne@hum.auc.dk \\ http://www.hum.auc.dk/ansatte/marianne/
}

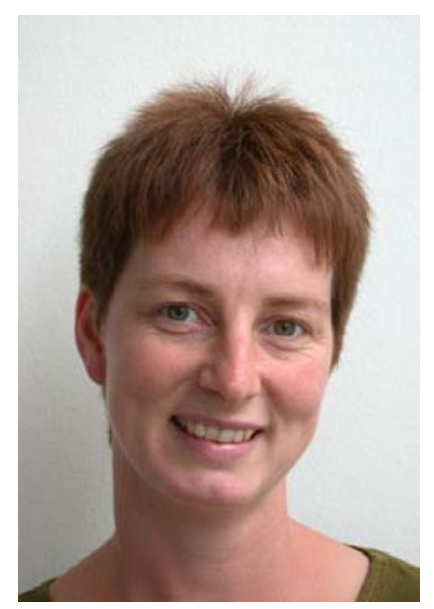

Marianne Georgsen er cand.mag. i humanistisk datalogi og sociologi. Adjunkt i IKT og loering v. Institut for Kommunikation, Aalborg Universitet.

Kommunikation, dialog og samarbejde er vigtige ingredienser i en moderne læringsforståelse. Derfor er viden om, hvad der får kommunikation til at fungere af afgørende betydning for netbaserede undervisnings- og læringsformer, hvor kommunikation og anden interaktion finder sted på tværs af tidslige og geografiske forskydninger. Dette er en vigtig del af grundlaget for at kunne udvikle bæredygtige netbaserede læringsuniverser. Denne artikel stiller skarpt på de "små ting" i kommunikationen med det formål at øge bevidstheden om, hvilke teknikker vi benytter os af, når vi undervejs i kommunikation med andre formidler vores forståelse af samtalen og interaktionen.

Først vil jeg præsentere en moderne læringsforståelse, som sætter den lærende i centrum. Fokus er således på den lærende og dennes aktive videnstilegnelse og videnskonstruktion, og kommunikation og dialog bliver vigtige redskaber i arbejdet med at nå de pædagogiske mål. Dernæst introduceres Herbert Clarks kommunikationsforståelse med det formål at skærpe opmærksomheden på centrale faktorer i forbindelse med mediering af kommunikation. Efter en opsummering af de kommunikative betingelser i virtuelle miljøer illustrerer jeg de grundlæggende principper i kommunikationsforståelsen i forhold til en velbeskrevet pædagogisk arbejdsform med vægt på netop kommunikation. Jeg afslutter med på denne baggrund at knytte forbindelse mellem forskellige læringsformer og pædagogiske arbejdsformer og relevante kriterier for valg/design af læringsomgivelser.

\section{En moderne læringsforståelse}

Inden for de seneste 10 år er der sket et skift i den dominerende forståelse af læringsbegrebet, et skift som efterhånden på både teoretisk, praktisk og politisk niveau får større og større betydning for lærings- og undervisningsaktiviteter. Skiftet kan kort beskrives som en udvikling fra en formidlingsbaseret poedagogik mod en handlings- og aktivitetsbaseret loeringsforståel$s e$. Praktiseringen af forskellige pædagogiske former baserer sig på forskellige læringsfiloso- 
fier, hvor der i de senere år er sket en udvikling fra en individualistisk, videnscentreret og passiv læringsforståelse til en opfattelse af læring som en aktiv, konstruktivistisk og praksisog handlingscenteret proces. Denne læringsforståelse ligger eksempelvis til grund for flere, allerede kendte undervisnings- og læringsformer, f.eks. projektpædagogikken, erfaringspædagogikken og praksislæring. Inden for et sådant konstruktivistisk læringssyn betragtes viden som noget, der konstrueres på baggrund af allerede eksisterende viden. I mødet mellem individuelle lærende, som rummer hver deres konstruktive processer, finder forhandling af mening sted, når det nye læres, ligesom vi på sin vis også meningsforhandler med os selv. Denne forhandling og meningsdannelse kan foregå på flere måder og i flere forskellige fora, og kommunikation af vores forståelse af et givent fænomen bliver dermed en nødvendig del af læreprocessen. Læringsudbyttet er person- og praksisbundet og må derfor gøres synligt gennem kommunikative processer, hvor den lærende udtrykker sin (konstruerede) forståelse af vidensområdet. Der ligger for så vidt en pointe i, at selve ekspliciteringen af forståelsen er en integreret del af læreprocessen. Betingelserne for kommunikation er denne artikels egentlige omdrejningspunkt.

Et andet forhold, som bringer kommunikationen i fokus, er, at underviserrollen udvikler sig fra, at læreren er en central figur, hvis tilstedeværelse er en forudsætning for, at der kan finde læring sted, til at den lærende og dennes aktive processer kommer i centrum. For at kunne arbejde målrettet mod opstillede pædagogiske mål må læreren iværksætte aktiviteter, der giver indsigt i den lærendes forståelse af det, der arbejdes med. Det kan f.eks. være mundtlige eller skriftbaserede dialoger eller diskussioner, studenter-præsentationer, skriftlige opgaver eller mundtlige oplæg for medstuderende og undervisere, etc.

Endvidere lægger en konstruktivistisk læringsforståelse samt en mindre central lærerrolle op til en større grad af samarbejde mellem de lærende, og som sådan kommer kommunikationen endnu en gang i fokus. Det kommunikative aspekt ved gruppeorienterede og dialogbaserede arbejdsformer og læringsaktiviteter behandles i mange sammenhænge, og særligt i forbindelse med diskussion af didaktik og pædagogiske modeller for læring i virtuelle miljøer (se f.eks. Fjuk \& Dirckinck-Holmfeld 1997; Sorensen 2000). Mens disse kilder forholder sig konstaterende til kommunikationens betydning, fokuserer de imidlertid ikke på betingelserne herfor i nævneværdig grad, da fokus i højere grad ligger på diskussion af betydningen af designet af læringsmiljø og -aktiviteter for at facilitere konstruktivistiske læreprocesser.

Den ændrede læringsfilosofi giver i disse år anledning til en række synlige ændringer i det danske uddannelsessystem, hvoraf en af de større udviklinger er indførelsen af projektarbejdet som pædagogisk form på grundskoleniveau, ligesom en række vekseluddannelser inden for erhvervsuddannelsessystemet i de senere år har undergået revision. Et tredje område, hvor der udvikles og eksperimenteres med nye undervisnings- og læringsformer er på de ellers så traditionelle universiteter, hvor der særligt inden for efter- og videreuddannelsesområdet er en spændende udvikling i gang. I tillæg til de pædagogiske bevægelser ses også en stigende brug af netbaseret undervisning og læring, som rejser nye udfordringer for både undervisere og studerende. Udbredelsen af netbaserede uddannelsesforløb ses bl.a. i det stigende antal master- og diplomuddannelser, der tiltrækker studerende fra hele landet i kraft af fleksible og netbaserede undervisnings- og arbejdsformer. Både pædagogiske, kommunikative såvel som teknologiske problemstillinger forbundet med udvikling og afvikling af netbaseret læring optager et stort antal forskere og undervisere $i$ det danske universitetssystem. I mange sammenhænge arbejdes der både eksperimentelt og på grundforskningsniveau med disse problemstillinger, som ofte giver anledning til tværfaglige samarbejder for bedre at kunne håndtere områdets kompleksitet og mangfoldighed af udfordringer (se eksempelvis http://www.ell.auc.dk for en præsentation af det AAU-baserede VILL-projekt eller http://qp.ell.auc.dk/flexnet for 
præsentation af it-vest projektet Flexnet), ligesom flere og flere universiteter får centre eller kompetenceenheder, der arbejder med området.

Forud for en nærmere undersøgelse af vilkårene for kommunikation i virtuelle omgivelser skal vi imidlertid kigge nærmere på nogle grundlæggende aspekter ved kommunikation, som har betydning for hvordan den kan medieres. Vi vender blikket mod den amerikanske psykolog Herbert Clarks arbejde med at beskrive kommunikation som et samarbejde mellem de kommunikerende.

\section{Kommunikation - et samarbejde om forståelse}

Kommunikation handler i bund og grund om at skabe mening. Vi tager initiativ til meningsskabelse, når vi siger noget. Den meningsskabende proces forudsætter, at det, vi siger, høres eller på anden vis opfattes af andre. Etableringen af forståelse bekræftes løbende gennem tale og andre former for handling, det vil sige, at enhver handling i en interaktion baserer sig på en fortolkning og deraf følgende forståelse af den eller de foregående handlinger. Så længe interaktionen giver mening for alle involverede parter, kan vi handle uden tvivl. I det øjeblik en af de involverede ikke kan skabe mening i det, der siges eller gøres, bryder situationen sammen og må så at sige genoprettes eller repareres. Således beskriver Herbert Clark (1996) fænomenet kommunikation som en situeret meningsforhandling, hvor ytringer og feedback på ytringer indgår i et komplekst samspil. Clark ser endvidere kommunikation som noget, der foregår $i$ et delikat samarbejde mellem de kommunikerende parter.

Kommunikation kan endvidere karakteriseres ved to centrale fænomener, siger Clark, nemlig: 1. "Common ground", dvs. at deltagelse forudsætter et vist fælles grundlag eller fundament blandt deltagerne, som de handler på baggrund af, når de kommunikerer.

2. Akkumulation - kommunikationsprocessen er akkumulativ på den måde, at deltagerne undervejs i interaktionen forsøger at føje til/udvide deres fælles fundament. (Clark \& Schafer 1989).

Hvordan tilkendegives det, at denne udvidelse finder sted? Hvordan ser vi, at deltagerne forstår hinanden, og at en handling har bidraget til et styrket fælles forståelsesgrundlag? Som middel til at etablere den fælles opfattelse, at Bent har forstået, hvad Anne mente, har vi brug for en systematisk procedure. Denne systematiske proces kalder Clark for fundering (fra engelsk "grounding"), hvorom han siger:

"Grounding criterion: the contributor and the partners mutually believe that the partners have understood what the contributor meant to a criterion sufficient for current purposes." (Clark \& Schafer 1989: 262).

For at bruge funderingsbegrebet analytisk rejser der sig umiddelbart et spørgsmål om, hvordan det afgøres, hvad der er tilstrækkeligt for det aktuelle formål ("current purposes")? Clark fremstiller det på den måde, at netop fordi der er tale om situationsbunden konstruktion af forståelse (som sker "moment-by-moment" i interaktionen) vil det kunne afgøres i situationen, om kriteriet er opfyldt. Hvis kriteriet ikke opfyldes, vil det afsløre sig i kommunikationen på den måde, at en næste handling (ytring eller kropslig handling) ikke demonstrerer forståelse af den eller de foregående handlinger, og situationen vil bryde sammen. Sådanne nedbrud i kommunikationen sker hele tiden, og som oftest lykkes det deltagerne at reparere dem uden at nogen oplever nedbruddet som andet end en naturlig del af kommunikationen. Et helt banalt eksempel på et nedbrud er, når vi ikke kan høre hvad vores samtalepartner siger og indskyder et "hva'?", der følges op af en gentagelse, hvorefter kommunikationen fortsætter sin progression. Selv om dette i de allerfleste tilfælde vil passere ubemærket hen som en selvfølgelig del 
af det at tale med andre, vil det i nogle situationer være så skadeligt for kommunikationen, at det ikke er muligt at reparere situationen.

Clark og Schaefer (1989: 267) taler om funderingsteknikker som det, de kalder "evidence of understanding" i forhold til det førnævnte funderings-kriterium. De nævner fem hovedtyper af teknikker til demonstration af forståelse i samtaler, som alle er umiddelbart genkendelige fra dagligdags kommunikationssituationer. Vi kan i udgangspunktet antage, at jo mere kompliceret A's præsentation er, jo stærkere virkemidler kræves der for at overbevise A om, at B har forstået indholdet. I nedenstående fremstilling er teknikkerne præsenteret med den svageste teknik øverst, og den stærkeste nederst. Den svageste teknik er samtidig den mindst krcevende at udføre, ligesom den stoerkeste teknik er den mest krcevende form.

1. Fortsat opmoerksomhed. Hermed menes, at B med tilkendegivelse af fortsat at høre efter (f.eks. ved at fastholde øjenkontakt) indikerer, at hun forstår, hvad A siger.

2. Initiering af et relevant noeste bidrag. Forståelse kan også demonstreres gennem at kunne foretage en forventelig handling som respons på det, man har hørt, som f.eks. når tjeneren noterer ens ordre på sin blok (tjenere, der ikke skriver noget ned, skaber ofte usikkerhed hos kunden om, hvorvidt ordren er forstået), eller når man reagerer på et spørgsmål med et svar. 3. Bekraftelser. Disse kan tage form som nik med hovedet eller bekræftende lyde. Denne form for demonstration af forståelse er det, vi ofte tænker på som respons eller feedback i kommunikation.

4. Demonstration. Som eksempel på dette kan nævnes kursisten på pc-kørekort-kurset, der efter lærerens instruktion til "gem" - funktionen klikker på det rigtige ikon på skærmen, og hermed demonstrerer forståelse af budskabet.

5. (Ordret) gengivelse. Ordret gengivelse bruges, hvor der er særligt behov for at give præcise informationer videre, som f.eks. et telefonnummer, hvor det ikke er nok at have hørt noesten alle tallene.

En ofte refereret erfaring med medieret kommunikation er, at det er "mere besværligt" at kommunikere gennem medier, f.eks. breve/mails, telefon, etc. Det kan forklares i kraft af, at medierne ikke indeholder mulighed for at anvende de mindre krævende funderingsteknikker. Vi ved, at fraværet af den umiddelbare respons (i f.eks. skriftbaseret kommunikation eller anden tidsforskudt interaktion) opleves af mange som en belastning, og som noget der skaber usikkerhed i kommunikationen. Dette ses bl.a. derved, at vi f.eks. som afsender af breve bruger energi på at beskrive vores følelser og sindstilstand, noget der ved ansigt-til-ansigt samvær ofte vil kunne afkodes i situationen. Omvendt bruger vi som modtager af skriftlig kommunikation betragteligt mere energi på at afkode meddelelserne, hvilket vi bl.a. gør ved at spørge eksplicit til det, vi ikke forstår ud fra teksten. Begge forhold er med til at gøre kommunikationen mere krævende end eksempelvis ansigt-til-ansigt eller medieret verbal kommunikation. En vigtig pointe i Clarks teori er således, at fundering kræver positiv tilkendegivelse, dvs. det er ikke tilstrækkeligt, at vi ikke får bevis for, at kommunikationen er brudt sammen. En del af forklaringen på oplevelsen af den øgede anstrengelse i forbindelse med medieret kommunikation kan altså forklares som mangel på positiv tilkendegivelse af, at forståelse finder sted.

Clarks funderingsteknikker beskriver, hvordan processen med etablering og udvidelse af det fælles grundlag etableres i ansigt-til-ansigt kommunikation. En vigtig pointe i tillæg til dette er, at funderingen i ansigt-til-ansigt kommunikationen foregår på det sproglige såvel som det ikke-sproglige og til dels også ikke-bevidste plan (jf. Bygholm 2002). 
Et andet grundlæggende princip hos Clark er det, han kalder principle of least collaborative effort, som handler om det forhold, at deltagerne altid vil forsøge at fundere forståelsen med den mindst mulige indsats:

"The principle of least collaborative effort: In conversation, the participants try to minimize their collaborative effort - the work that both do from the initiation of each contribution to its mutual acceptance." (Clark \& Brennan 1991: 135).

Som det fremgår, retter princippet om mindst mulig indsats sig mod kommunikation generelt og dermed også mod funderingsprocessen. Set i relation til funderingsteknikkerne er det åbenlyst, at de stærkeste virkemidler (f.eks. ordret gengivelse) også kræver den største indsats, og anvendelsen af dem vil givet kunne opleves som en forøgelse af det arbejde, kommunikationen indebærer. Det virker rimeligt at antage, at den mindst mulige indsats $i$ en medieret kontekst altid være større end i en ikke-medieret kontekst. Denne antagelse er bl.a. baseret på arbejde af Fjuk og Dirckinck-Holmfeld (1997), som illustrerer, hvorledes virtuelle miljøer stiller krav om større grad af artikuleringsarbejde, dvs. metakommunikation eller eksplicitering af funderingsarbejdet.

\section{Kommunikation i virtuelle rum}

Vilkårene for samarbejde og kommunikation i virtuelle rum præges naturligvis af de virtuelle omgivelsers muligheder og begrænsninger. Deltagerne vil typisk være adskilt geografisk og ofte også være tidsligt forskudt for hinanden. Disse to vilkår for interaktionen har givet anledning til brug af primært skriftbaserede kommunikationsformer, som det f.eks. ses i konferencesystemer og mail-systemer. I mange tilfælde er det muligt (i hvert fald lejlighedsvis) at etablere synkron kommunikation, som kan være skriftbaseret (chat, SMS) eller audio- og/eller videobaseret (telefonmøder, videokonferencer). Der er forskellige konsekvenser af forskydningerne og af de værktøjer der vælges til at mediere hen over dem med. For eksempel har den skriftbaserede kommunikation (både den synkrone og den asynkrone) etableret sig som stærk i forhold til at skabe reflekteret dialog (Sorensen 2000), mens den har vist sig svag i forhold til ideudvikling og koordinering (se f.eks. Fjuk \& Dirckinck-Holmfeld 1997).

Skriftliggørelsen er i sig selv blevet problematiseret, f.eks. i forhold til den arbejdsindsats den kræver, og de krav der stilles til deltagernes skriftlige formåen for at "klare sig godt" i et udelukkende skriftbaseret miljø. Et andet væsentligt problem i forhold til den asynkrone kommunikation er fraværet af kontekst-information, som igen er med til at øge deltagernes arbejdsindsats, hvis der skal kompenseres for dette.

Hvis vi ser på Clarks typer af funderingsteknikker, fremgår det, at de svageste teknikker kun vil have ringe gennemslagskraft i en medieret kontekst. Det er ganske simpelt ikke muligt at opnå øjenkontakt i virtuelle omgivelser, ligesom fatisk kommunikation i skriftbaserede omgivelser næsten umuliggøres af kommunikationens sekventielle karakter (kun én kan "tale" ad gangen). Fatisk kommunikation har lidt bedre vilkår i synkron kommunikation, og særligt hvis der er tale om audio eller videomedieret interaktion, men vanskeliggøres stadig af forskellige forhold, som jeg vil komme ind på senere.

Disse forhold, kombineret med ønsket om at kommunikere med mindst mulig indsats, forklarer delvist oplevelser af, at medieret kommunikation er mere besværlig end ansigt-til-ansigt. Kommunikation i virtuelle miljøer kræver nemlig mere artikulationsarbejde, og endvidere bliver udvikling og brug af nye former for artikulation ofte nødvendigt. Der er forskellige måder at tage højde for dette på, eksempelvis målrettet udvikling af nye artikulationsformerformer eller design af kommunikationsværktøjer ud fra disse forhold. Jeg har i det følgende valgt at illustrere betydningen og funktionen af disse funderingsteknikker gennem en kendt og forholdsvis velbeskrevet pædagogisk form, nemlig projektpædagogikken. Ved at koble Clarks 
begreber til projektarbejdets forskellige faser og de kommunikative krav, der knytter sig hertil, ønsker jeg især at illustrere, hvordan princippet om "least effort" kan og bør få indflydelse på vores valg af kommunikationsværktøj, og indirekte hvordan det læringsmæssige udbytte påvirkes, hvis det ikke sker. Endvidere vil jeg på baggrund af fremstillingen af projektarbejdets faser og kommunikative behov og Clarks funderingsteknikker forsøgsvis opstille retningslinier for valg af kommunikationsteknologier.

\section{Kommunikation i kollaborativt projektarbejde}

Med udgangspunkt i projektpædagogikken som et eksempel på en konstruktivistisk og kollaborativ lærings- og arbejdsform illustreres i det følgende nogle af de kommunikative forhold, der gør sig gældende, når kommunikation foregår i netbaserede eller virtuelle omgivelser. På Aalborg Universitet (AAU, http://www.auc.dk/aaben/udd/) har man i en årrække udbudt efter- og videreuddannelse, som har det problemorienterede projektarbejde som et af de bærende principper for strukturering af uddannelserne. Også på netbaserede uddannelsesforløb lægges der op til, at projektarbejdet foregår i grupper, hvilket stiller store krav til de studerendes kommunikation og samarbejde. Dette er f.eks. tilfældet på en række masteruddannelser på AAU, der alle afvikles som en kombination af netbaseret aktivitet og fysisk fremmøde på weekendseminarer. Her har man i flere år praktiseret forskellige former for teknologistøtte til det gruppebaserede projektarbejde. Erfaringerne herfra viser, at gruppebaseret projektarbejde ikke uden videre bliver vellykket i virtuelle rum, og at der må lægges overordentligt mange kræfter i at få samarbejdet til at fungere (se f.eks. Dirckinck-Holmfeld 2000; Helbo et al. 2001; Georgsen 1995). Det virker derfor rimeligt at antage, at en større bevidsthed om kommunikative redskaber koblet med teknologisk fantasi vil kunne mindske indsatsen ved at arbejde kollaborativt i virtuelle miljøer og således øge læringsudbyttet for deltagerne.

\section{Projektarbejdets faser}

Med udgangspunkt i praksis på forskellige uddannelser på AAU kan et projektarbejdsforløb inddeles i tre hovedfaser med tilhørende karakteristiske opgaver, arbejdsprocesser og kommunikative behov:

\section{Etableringsfasen}

Gruppedannelse, valg af emne/problemfelt, problemformulering, opstilling af disposition og arbejds-/tidsplan, idé-fase.

Arbejdsprocesserne er bl.a.: Brainstorming, diskussion, læsning, formulering, etablering af fælles mål, afgrænsning.

Kommunikative behov: Tæt, intensiv kommunikation, meningsudveksling, "korte svartider", konsensusdannelse.

\section{Forskningsfasen}

Indsamling af data, interviews, spørgeskemaer, målinger, forsøg, læsning, fremstilling af arbejdspapirer/noter.

Arbejdsprocesserne er: Læsning, skrivning af noter/arbejdspapirer, tilrettelæggelse og udførelse af konkrete undersøgelser/dataindsamlinger.

Kommunikative behov: Individuelt arbejde, kommunikation i undergrupper.

\section{Fremstillingsfasen}

Produktion af prototype, pjece, video, applikation, rapport, mv. Fremstilling af afsnit til projektrapport.

Arbejdsprocesserne er: Skrivning af afsnit, læsning og diskussion af oplæg/arbejdspapirer, koordinering, versionshåndtering. 
Kommunikative behov: Skriftlig bearbejdning, udveksling og diskussion af materialer, versionsstyring, konsensusvedligeholdelse.

En tilsyneladende banal erkendelse med relativt generel dækning går på, at forskellige typer af aktiviteter har forskellige kommunikative behov. På trods af banaliteten er dette alligevel centralt i forhold til at ville understøtte noget så komplekst som projektarbejde ved hjælp af IKT, og det viser sig, at det ikke er banalt at finde gode løsninger hertil. I forhold til opdelingen i de tre faser og de forskellige typer af aktiviteter, der karakteriserer disse, er det klart, at kommunikationsbehovene varierer gennem projektarbejdets forløb. Det er ligeledes klart, at den kollaborative indsats varierer tilsvarende. Der er blandt andet tale om, at behovet for fælles fundament ("common ground") blandt deltagerne vil variere, og eksempelvis vil der i etableringsfasen skulle bruges megen energi på også at etablere det fælles fundament. Der vil $i$ både forskningsfasen og fremstillingsfasen være brug for visuel adgang til de fælles artefakter og arbejdsredskaberne (f.eks. prototyper, data-eksempler, tekster, etc.). Hvis der ikke er det (hvis kommunikationsværktøjerne eksempelvis kun tillader skriftbaseret kommunikation), stiger den kommunikative indsats med at beskrive og referere til artefakter og tekster.

\section{Kommunikationsteknologiske løsninger}

Ved valg af en teknologisk løsning til mediering af kommunikation og samarbejde er det væsentligt at være bevidst om, hvad vi benytter os af, når vi etablerer forståelse (jf. eksemplerne ovenfor). Inspireret af Clark er der tre væsentlige "domæner", som vi gør brug af i kommunikationen, nemlig deltagerne, arbejdsgenstandene og den lokale geografi. Det er indlysende, at forskellige teknologier giver adgang til forskellige domæner, og særligt hvis der er behov for visuel adgang til domænerne begrænses vores teknologiske muligheder. Visuel adgang kan f.eks. etableres gennem videoforbindelser, som viser deltagerne, dele af deres omgivelser og/eller de genstande, der bruges i forbindelse med samarbejdet. Det er langt fra altid nødvendigt at give visuel adgang til deltagerne (selv om det er sædvanligvis gives førsteprioritet, hvis der er mulighed for at etablere videoforbindelse). Bennedsen og Caspersen (1996) beskriver eksempelvis et undervisningsforløb, hvor underviserens gennemgang af programmeringsøvelser i et netbaseret forløb ledsages af videooptagelser af underviserens computerskærm (frem for af læreren selv). Dette giver de studerende adgang til det, læreren gør, hvilket spiller en central rolle i konstruktionsorienteret undervisning.

Visuel adgang kan også etableres gennem brug af et fælles whiteboard eller en fælles skærm, hvor alle deltagere har mulighed for at skrive eller tegne, pege, samt se hvor de øvrige deltagere skriver og peger. Dette er eksempelvis nyttigt i forbindelse med fremstilling af og kommunikation om produkter. Visuel adgang behøver ikke være "live", eksempelvis kan et fast billede på et whiteboard være et bedre udgangspunkt for en grundig diskussion af detaljerne $\mathrm{i}$ et designforslag end en video, som ikke fastholder detaljer og produkter, men derimod har sin styrke $\mathrm{i}$ forhold til at illustrere forløb og processer.

Etableringsfasen i et samarbejde er ofte kendetegnet ved megen og intensiv kommunikation, og anses ofte som vanskelig at gennemføre i virtuelle miljøer (se f.eks. Georgsen 1995). Denne observation hænger til dels sammen med, at studier af dette er foretaget $\mathrm{i}$ asynkrone skriftbaserede læringsomgivelser, og det må antages, at synkrone og videobaserede omgivelser giver forbedrede muligheder for at støtte idéudviklende og konsensusorienterede aktiviteter. Det vil i så fald være centralt at give størst mulig adgang til deltagerne, og formentlig vil lyd og billede bidrage til, at kommunikationen bliver mindre krævende. En interessant observation i forbindelse med videomedieret kommunikation, som har indflydelse på deltagernes kommunikative indsats, handler om fænomenet "delay" eller forsinkelse (se f.eks. Gutwin 2001 eller Ruhleder \& Jordan 2001). De fleste internetbaserede videoforbindelser er udsat for 
forsinkelse af billedet, hvilket medfører at lyd og billede ikke er synkroniseret. Deltagerne skal således løbende bruge energi på at synkronisere det, de ser, med det, de hører, hvilket strider imod Clarks princip om mindst mulig indsats. Det bør således overvejes, om billedet er vigtigt, eller om det er mindre krævende for deltagerne i nogle situationer "kun" at have lydforbindelse, hvor der ikke skal bruges energi på synkronisering (men derimod måske på identifikation af hvem der taler).

Jeg har her givet nogle eksempler på hvilke konsekvenser, der kan udledes af bestemte kommunikative behov. Med udgangspunkt i Clarks begreber om fundering, mindst mulig indsats og (evt. visuel) adgang til tre vigtige domæner er banen kridtet op for at identificere kommunikationsbehov i forbindelse med forskellige arbejdsprocesser. Når dette kobles med kendte teknologiske muligheder, kan arbejdet med at designe lokale situerede løsninger begynde. Et vigtigt udgangspunkt for dette arbejde må efter min mening være, at teknologier finder en form gennem og i brug, dvs. at det er nødvendigt at eksperimentere for at få den fornødne erfaring med forskellige teknologiske muligheder.

\section{Konklusioner i forhold til didaktisk design}

Her til slut vil jeg kort opridse nogle af hovedpointerne fra artiklen. Jeg finder, at Clarks begrebsapparat vedrørende kommunikationens vilkår er med til at skærpe vores blik for nogle konkrete og centrale områder, som vi skal koncentrere os om, når vi udformer pædagogisk, didaktisk og teknologisk design af netbaserede læringsomgivelser. Det drejer sig om følgende:

- Den "rigeste" kommunikationsform er ikke altid den mest velegnede - der er altid behov for at vurdere, hvilke kvalitetskriterier og relevanskriterier der gælder for den pågældende situation i forhold til valg af teknologi.

- Viden om kommunikation og dens vilkår hjælper - det er således vigtigt med bevidsthed om dette, og vigtigt at denne viden søges omsat i adfærd (det gælder både for undervisere og studerende).

- Kommunikationens vilkår kan illustreres gennem øvelser for deltagerne, og kan dermed fungere som igangsætter for deltagernes læreprocesser (f.eks. som led i et introkursus til netbaseret kommunikation i forbindelse med start på en netbaseret uddannelse).

- Meta-kommunikation er vigtigt, og læringsomgivelser bør designes, så der bliver mulighed for dette. I flere uddannelser indgår etablering af rammer for metakommunikation som en del af uddannelsens indhold, da det ikke er ligetil og samtidig helt fundamentalt for at der kan finde læring sted.

En væsentlig pointe i forhold til valg af teknologisk løsning er forbundet med det, jeg tidligere omtalte som teknologisk fantasi. Gennem brug af teknologien udvikler vi lokale brugsmønstre og nye brugsformer, og på forskellig vis lykkes det mange gange at interagere på trods af de tilsyneladende begrænsninger og muligheder, som de forskellige medier besidder. Konkret, situationsbunden brug af teknologi er en realisering af det mulighedsrum den aktuelle situation udgør, og det betyder, at alle muligheder i en teknologi ikke nødvendigvis udnyttes (f.eks. fordi deltagerne/brugerne ikke har de fornødne kompetencer). På samme måde kan der lokalt udvikles løsninger og kulturer, som overvinder nogle af de barrierer, den forhåndenværende teknologi opstiller (se f.eks. Georgsen and Raudaskoski 2002 for eksempler på dette). Der er således al mulig grund til at arbejde eksperimenterende med IKT-understøttelse af kommunikation, så vi fortsat får en erfaringsbaseret og fantasifuld tilgang til didaktisk og teknologisk design. 


\section{Litteratur}

Bennedsen, Jens og Michael Caspersen. "Rationale for the Design of a Web-based Programming Course for Adults". Proceedings for International Conference on Open and Online Learning, Mauritius, 2003. (under udgivelse).

Clark, Herbert. Using Language. Cambridge: Cambridge University Press, 1996.

Clark, Herbert, and Susan Brennan. "Grounding in Communication." Perspectives on Socially Shared Cognition. Eds. Lauren Resnick, John Levine and Stephanie Teasley: American Psychological Association, 1991.

Clark, Herbert, and E. Schafer. "Contributing to Discourse." Cognitive Science.13 (1989): 259-94.

Dirckinck-Holmfeld, Lone. "Virtuelle Læringsmiljøer På Et Projektpædagogisk Grundlag." At Undervise Med Ikt. Ed. Simon Heilesen: Samfundslitteratur, 2000.

Fjuk, Annita, and Lone Dirckinck-Holmfeld. "Sammenføyningsarbeid i Distribuerte Kollektive Læreprocesser." Loering og Multimedier. Ed. Oluf Danielsen, 1997.

Georgsen, Marianne. "Den Anden Dimension. Computermedieret Kommunikation Og Collaborative Learning." Aalborg Universitet, 1995. Speciale v. Institut for Kommunikation.

Georgsen, Marianne, and Pirkko Raudaskoski. "What Is Local Practice in Technology Mediated Environments? Video Analyses of Situated Interaction and Learning." Learning in Virtual Environments. Eds. Lone Dirckinck-Holmfeld and Bo Fibiger, 2002.

Gutwin, Carl. "The Effects of Network Delays on Group Work in Real-Time Groupware." Proceedings of the Seventh European Conference on Computer Supported Co-operative Work. Eds. Wolfgang Prinz, et al., 2001. 299-318.

Helbo, Jan et al. "Group Oriented Project Work in Distance Education". Proceedings of ITHET 2001 Conference, Kuanamoto, 2001.

Ruhleder, Karen, and Brigitte Jordan. "Co-Constructing Non-Mutual Realities: DelayGenerated Trouble in Distributed Interaction." Computer Supported Cooperative Work (CSCW) 10.1 (2001): 113-38.

Sorensen, Elsebeth. "Interaktion Og Læring i Virtuelle Rum." At Undervise Med IKT. Ed. Simon Heilesen: Samfundslitteratur, 2000. 235-56. 